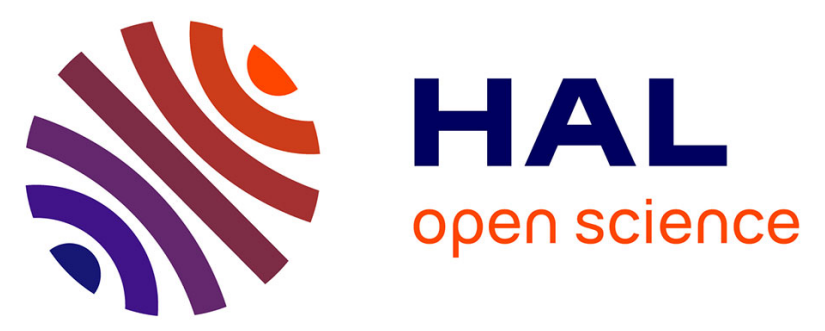

\title{
Distribution of two Agrobacterium tumefaciens insertion elements in natural isolates: Evidence for stable association between Ti plasmids and their bacterial hosts
}

François Paulus, Michel Ride, Léon Otten

\section{- To cite this version:}

François Paulus, Michel Ride, Léon Otten. Distribution of two Agrobacterium tumefaciens insertion elements in natural isolates: Evidence for stable association between Ti plasmids and their bacterial hosts. Molecular and General Genetics MGG, 1989, 219. hal-01600800

\section{HAL Id: hal-01600800 \\ https://hal.science/hal-01600800}

Submitted on 2 Jun 2020

HAL is a multi-disciplinary open access archive for the deposit and dissemination of scientific research documents, whether they are published or not. The documents may come from teaching and research institutions in France or abroad, or from public or private research centers.
L'archive ouverte pluridisciplinaire HAL, est destinée au dépôt et à la diffusion de documents scientifiques de niveau recherche, publiés ou non, émanant des établissements d'enseignement et de recherche français ou étrangers, des laboratoires publics ou privés.

\section{다(1)(2)}

Distributed under a Creative Commons Attribution - ShareAlikel 4.0 International 


\title{
Distribution of two Agrobacterium tumefaciens insertion elements in natural isolates: Evidence for stable association between Ti plasmids and their bacterial hosts
}

\author{
François Paulus ${ }^{1}$, Michel Ride ${ }^{2}$, and Léon Otten ${ }^{1}$ \\ ${ }^{1}$ Institut de Biologie Moléculaire des Plantes du CNRS, Rue du Général Zimmer 12, F-67084 Strasbourg, France \\ 2 INRA. Route St. Clément, F-49070 Beaucouze, Angers, France
}

\begin{abstract}
Summary. A large number of Agrobacterium tumefaciens strains of the biotype III group carry two to ten copies of two related IS elements, IS866 and IS867. A study of the distribution and localization of these elements in 54 strains showed that one IS866 and two IS867 copies are always found at characteristic sites on the octopine/cucumopine and vitopine Ti plasmids, whereas varying amounts of IS866 and IS867 copies occur at different positions on the chromosome. By comparison of the IS patterns, an evolutionary tree could be deduced which shows the phylogenetic relationships between 23 different types of Agrobacterium strains. The structures of the T-regions of the different strains were also compared. Within the octopine/cucumopine group, eight T-region patterns could be defined. These patterns were found to be correlated with the chromosomal IS patterns. This strongly suggests that the IS866 and IS867 containing Ti plasmids are stably associated with their bacterial hosts. The possible role of the IS866 and IS867 elements in Ti plasmid evolution is discussed.
\end{abstract}

Key words: Agrobacterium - IS elements - Ti plasmid T-region - Bacterial evolution

\section{Introduction}

Agrobacterium tumefaciens is a gram-negative phytopathogenic bacterium. which induces tumours (crown galls) on a large number of plant species (Smith and Townsend 1907; De Cleene and Deley 1976). Tumour formation by Agrobacterium results from a remarkable example of natural genetic engineering. During the infection process, one or two DNA fragments (T-regions) are transferred to the plant cell and are stably integrated in the nuclear genome. The T-regions are carried by a large tumour inducing (Ti) plasmid, and are composed of genes inducing plant cell growth (tumour genes or oncogenes) and genes coding for the production of low molecular weight compounds, called opines, which are used by the gall inciting bacterium for its growth. In addition to the $\mathrm{T}$-regions, the $\mathrm{Ti}$ plasmid carries genes needed for T-region transfer, the virulence genes (for reviews see Guyon et al. 1980; Nester et al. 1984; Zambryski et al. 1989).

Many different Agrobacterium strains have been described. They have been classified into three biotypes on the basis of chromosomal markers (Kerr and Panagopoulos

Offprint requests $t o:$ L. Otten
1977). The various strains often have very different host ranges and might be specially adapted to particular hosts or environments. In most cases, host range determinants were shown to be located on the Ti plasmid (Thomashow et al. 1980; Knauf et al. 1982; Hoekema et al. 1984; Buchholz and Thomashow 1984; Otten et al. 1985; Hood et al. 1986). Since the Ti plasmids have been shown to be conjugative (Petit et al. 1978), a classification scheme based on chromosomal markers may be of little use if one wants to investigate the phytopathological properties of the natural isolates.

For our studies on Agrobacterium host range determination and T-region structure, we have chosen to work with the biotype III strains, which are mainly found on grapevine. Crown gall on grapevine represents a serious agricultural problem, since the bacteria are easily propagated by the plantation of young, infected rootstocks, in which they are difficult to detect (Kerr and Panagopoulos 1977; Loubser 1978; Süle 1978; Perry and Kado 1982; Burr and Katz 1983; Burr et al. 1987; Bien 1988; Jäger 1988; Paulus et al. 1989). The biotype III strains have been classified into octopine/cucumopine, nopaline and vitopine strains (Szegedi et al. 1988). Many pathogenic biotype III strains have been isolated from all over the world, notably from vineyards in France, West Germany, Greece, Hungary, Bulgaria, Australia, South Africa, the United States, and China.

In earlier studies, we have proposed a new classification method for biotype III strains. This method is based on a restriction analysis of total bacterial DNA with biotype I derived T-region fragments and two related, biotype IIIspecific repeated elements, IS866 and IS867, which are closely linked to the T-regions of all biotype III vitopine and octopine/cucumopine strains (Paulus et al. 1989). IS866 is a 2716 bp bacterial insertion element with 27 -bp terminal repeats, generating 8-bp duplications at the target site (Bonnard et al. 1989 b). IS866 and IS867 are often found in multiple copies at different locations in the bacterial genome. Our classification studies showed that the octopine/cucumopine $\mathrm{Ti}$ plasmids have different but related $\mathrm{T}$-region structures. In the case of strains AB3 and Tm4, differences in tumour induction could be related to differences in Tregion structure (Bonnard et al. 1989a; Paulus et al. unpublished). We now report a detailed comparison of the IS and T-region patterns of a large number of biotype III strains which enabled us to establish the phylogenetic relationships between 23 types of Agrobacterium strains. 
Table 1. Bacterial strains used

\begin{tabular}{|c|c|c|c|c|c|}
\hline Strain & Origin & op & IS type & I & $\mathrm{T}$ \\
\hline $\mathrm{Sz} 1, \mathrm{Sz} 2$ & Hungary & $\mathrm{v}$ & 867-like & 1 & A \\
\hline Bazzi & Italy & & & & \\
\hline NW11 & Ruppertsberg, FRG & & & & \\
\hline NW113 & Friedelsheim, FRG & & & & \\
\hline NW121 & Kallstadt, FRG & & & & \\
\hline NW161 & Essingen, FRG & & & & \\
\hline S4 & Hungary & & & 2 & \\
\hline $\begin{array}{l}2612,2614,2675, \\
2676\end{array}$ & Brissac, France & $\mathrm{o} / \mathrm{c}$ & 867 & 3 & $\mathrm{~B}$ \\
\hline 2677 & Le Pallet, France & & & & \\
\hline 2617 & Savenières, France & & & 4 & \\
\hline 2651 & Le Pallet, France & & & & \\
\hline 2656 & Médoc, France & & & & \\
\hline AB3 & Hungary & & & & \\
\hline NW90 & Wachenheim, FRG & & & & \\
\hline NW102 & Deidesheim, FRG & & & & \\
\hline 2607 & Saint Estève, France & & & 5 & \\
\hline 2650 & La Chade, France & & & 6 & \\
\hline 2653 & Médoc, France & & & 7 & \\
\hline 2613,2644 & Brissac, France & & & 8 & \\
\hline 2886 & Vaucluse, France & & & & \\
\hline $\mathrm{Zw2}$ & Hungary & & & & \\
\hline $\mathrm{B} 10 / 7, \mathrm{AT} 6$ & Hungary & & & 9 & \\
\hline 2770 & Aisne, France & & 866 & 10 & $\mathrm{C}$ \\
\hline $\mathrm{H} 8 / 1$ & South Africa & & and & 11 & \\
\hline At2 & South Africa & & 867 & 12 & \\
\hline $\begin{array}{l}\text { 2615. } 2616,2618 \\
2645,2646 \\
2647,2648\end{array}$ & Brissac. France & & & 13 & $\mathrm{~F}$ \\
\hline 2649 & Le Pallet, France & & & 14 & $\mathrm{C}$ \\
\hline $\mathrm{K} 305, \mathrm{~K} 308$ & Australia & & & 15 & \\
\hline $\begin{array}{l}2652,2678,2679 \\
\quad 2680\end{array}$ & Angers, France & & & 16 & \\
\hline 2657,2686 & Chinon, France & & & 17 & \\
\hline 2608 & Lussac, France & & & 18 & $\mathrm{D}$ \\
\hline 2641 & Lussac, France & & & 19 & $\mathrm{E}$ \\
\hline NW33 & Leinsweiler, FRG & & & 20 & $\mathrm{H}$ \\
\hline NW70 & Walsheim, FRG & & & & \\
\hline NW244 & Ruppertsberg, FRG & & & 21 & \\
\hline $\operatorname{Tm} 4$ & Hungary & & & 22 & G \\
\hline Hm1 & Hungary & & & 23 & I \\
\hline
\end{tabular}

For details of IS patterns and T-region patterns see Tables 2 and 3 , respectively

op, opine type; I, IS pattern; T, T-region pattern; v, vitopine; o/c, octopine/cucumopine

\section{Materials and methods}

Bacterial strains and media. Table 1 lists the strains used and their characteristics as determined in this study. All strains belong to the biotype III group. The opine properties of most strains have been described earlier (Paulus et al. 1989). "Bazzi", NW11, NW113, NW121 and NW161 were classified as "null", i.e. neither octopine nor nopaline strains (Bien 1988) and are probably vitopine strains. NW33, NW70, NW90, NW102, NW244, 2770, 2886, H8/1 and At2 are octopine/cucumopine strains. The various isolates were colony purified on YEB (Leemans et al. 1983) and stored in $50 \%$ glycerol at $-80^{\circ} \mathrm{C}$. DNA was isolated from liquid YEB cultures which were initiated from single colonies grown on solid YEB medium at $28^{\circ} \mathrm{C}$.

$D N A$ isolation and Southern hybridization. Agrobacterium total DNA was isolated according to Dhaese et al. (1979).
Agrobacterium plasmid DNA was isolated according to Currier and Nester (1976), digested and separated on agarose gels, which were stained with ethidium bromide after electrophoresis. Southern transfer and hybridization was done by standard methods as described by Paulus et al. (1989). Gels of $0.5 \%$ to $1.2 \%$ agarose were used to separate large and small fragments, respectively.

\section{Results}

\section{Detection of IS866 and IS867 copies}

IS866 has been fully sequenced (Bonnard et al. 1989b), IS867 nearly completely. The two elements have a length of $2.7 \mathrm{~kb}$. They have $75 \%$ DNA homology and weakly cross-hybridize under normal hybridization conditions. To study the distribution of IS866 and IS867, total or plasmid DNA of different Agrobacterium strains was digested with HindIII or EcoRV and separated on $0.5 \%, 0.8 \%$ and $1.2 \%$ agarose gels. Blots were hybridized with an IS 866 fragment (F-1) or an IS867 fragment (F-7). The localization of IS866 and IS867 in two characteristic biotype III octopine/cucumopine strains, Tm4 and AB3, and of the F-1 and F-7 sequences is shown in Fig. 1.

The IS866 fragment revealed by the F-1 probe has no internal EcoRV or HindIII sites (Fig. 1). Thus, assuming structural conservation between the different IS866 copies, the IS866 probe F-1 will reveal a single EcoRV fragment (minimal size $2.7 \mathrm{~kb}$ ) and a single HindIII fragment (minimal size $1.8 \mathrm{~kb}$ ) for each IS866 copy. Similarly, the IS867 probe F-7 will reveal a single EcoRV fragment (minimal size $2.5 \mathrm{~kb}$ ) for each copy and, in the case of HindIII, two small internal fragments $(0.35$ and $0.52 \mathrm{~kb})$, one larger fragment (minimal size $1.7 \mathrm{~kb}$ ) and a second, very weakly hybridizing fragment (minimal size $0.2 \mathrm{~kb}$ ).

Since the size of the bands varied from 0.9 to $18 \mathrm{~kb}$, various gels were run to permit good size estimations. Each of the 49 different EcoRV bands was assumed to represent a complete IS copy, located at a specific position in the bacterial genome and was designated by IST (Insertion Sequence Tumefaciens), followed by a number (Table 2). The 54 bacterial strains shown in Table 1 could be divided into 23 groups, each with a specific IST pattern. Some IST elements were found to be located on the $\mathrm{Ti}$ plasmid, and could be identified as such by analysis of purified plasmid DNA and by using the previously determined Tm4 and AB3 T-region maps (Paulus et al. 1989). The other IST elements were found on the chromosome, and in some cases on non-Ti plasmids.

\section{Ti plasmid copies of IS866 and IS867}

One group of octopine/cucumopine strains (representative strain: AB3, Fig. 1) carries two IS867 elements on the Ti plasmid: immediately to the right of the TA region (IST-2), and at the right end of the TB region (IST-3). The remaining octopine/cucumopine strains, to which $\mathrm{Tm} 4$ belongs (Fig. 1), also carry the same IST-2 and IST-3 elements, but have in addition a single IS866 copy (IST-1) within the $i a a H$ gene of the TA region (Bonnard et al. 1989b). One exceptional strain, Hm1, carries a single IS866 copy on its Ti plasmid at an unknown position outside the TA auxin gene region (see also below). The small group of vitopine strains has two IS867-like elements on the Ti plasmid, which have strong homology to IS867 but lack the internal IS867 

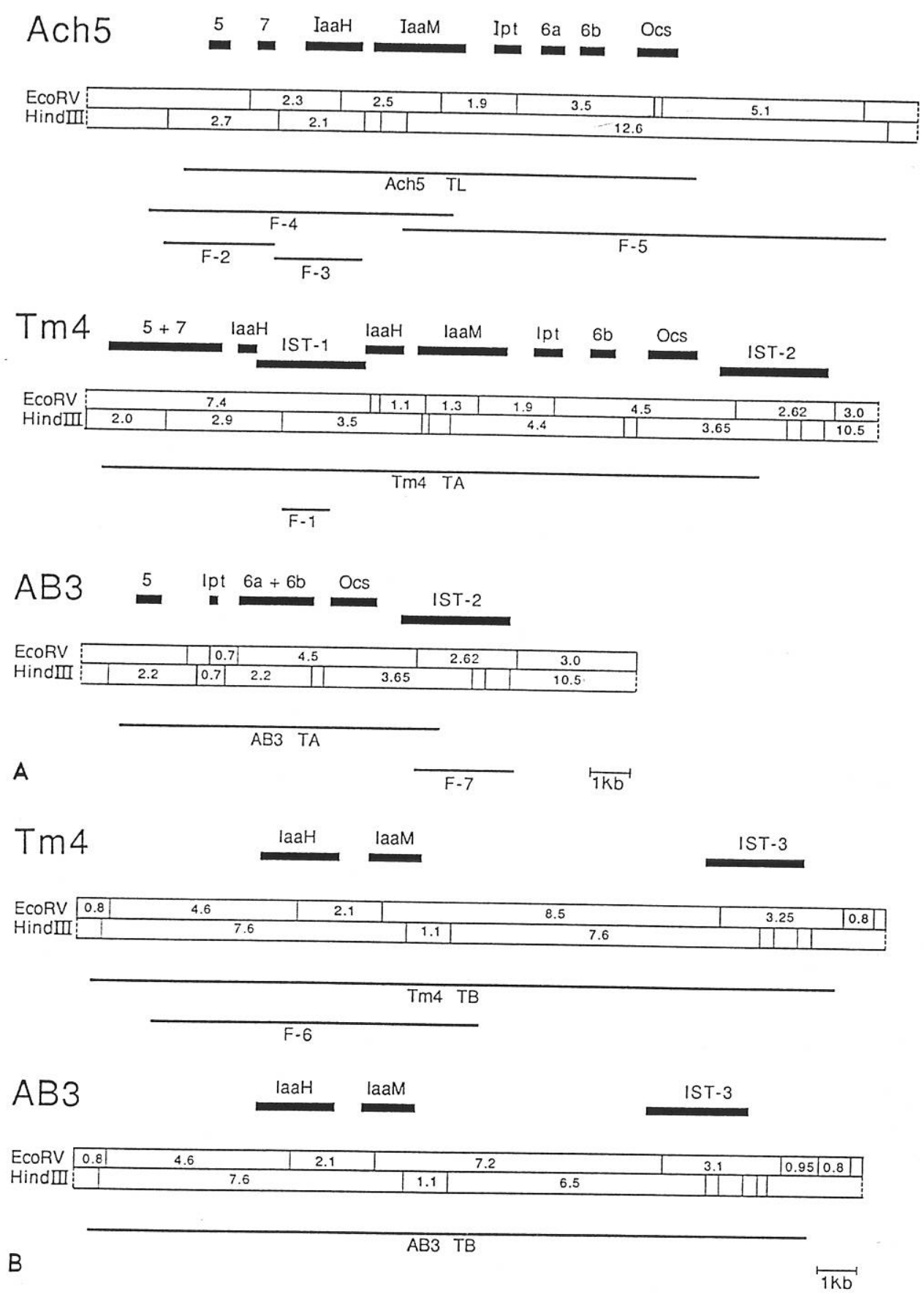

Fig. 1. A Maps of the TL region of Ach5 (Gielen et al. 1984) and of the TA regions of $\mathrm{Tm} 4$ and AB3 (Paulus et al. 1989). B Maps of the TB regions of $\mathrm{Tm} 4$ and $A B 3 . F-1$ to $F-7$ are probes used in the hybridization experiments, as described in the text. IST-1 is an IS866 copy, IST2 and IST-3 are IS867 copies. Filled bars: T-DNA genes and IST elements. Open bars: restriction fragments

B

HindIII sites. The vitopine Ti plasmids have little homology with previously described T-regions and the relationship between IS elements and T-region(s) has not yet been established. Finally, none of the 20 virulent biotype III nopaline isolates in our collection contains IS866 or IS867 (Paulus et al. 1989, Otten, unpublished).

\section{IS866 and IS867 copies outside the Ti plasmid}

The octopine/cucumopine strains either carry two IS867 copies on their Ti plasmids (IST-2 and IST-3), or two IS867 copies (IST-2 and IST-3) and one IS866 copy (IST-1, or in the case of Hm1 IST-44). These strains can be further subdivided, as the members of these groups carry various numbers of additional IS866 and IS867 copies. In most cases the copies are on the chromosome, and in a few cases they are on non-Ti plasmids, as shown by Southern analysis of digested and non-digested plasmid DNA, and by comparison with the IST patterns of related strains. Remarkably, most IST-1/IST-2/IST-3 strains also carry IS866 and IS867 elements outside the Ti plasmid, whereas the IST-2/ IST-3 strains carry chromosomal or non-Ti plasmid IS867 elements, but never IS866 elements. With the exception of S4, which carries an additional IS867-like element on a non-Ti plasmid, the vitopine strains do not have additional copies outside the ones on the Ti plasmid.

\section{Construction of an evolutionary tree}

Many of the IS866 and IS867 containing strains were found to have one to several bands in common, indicating descent from a common ancestor (Paulus et al. 1989). For example, 
148

Table 2. IS866 and IS867 elements in different strains

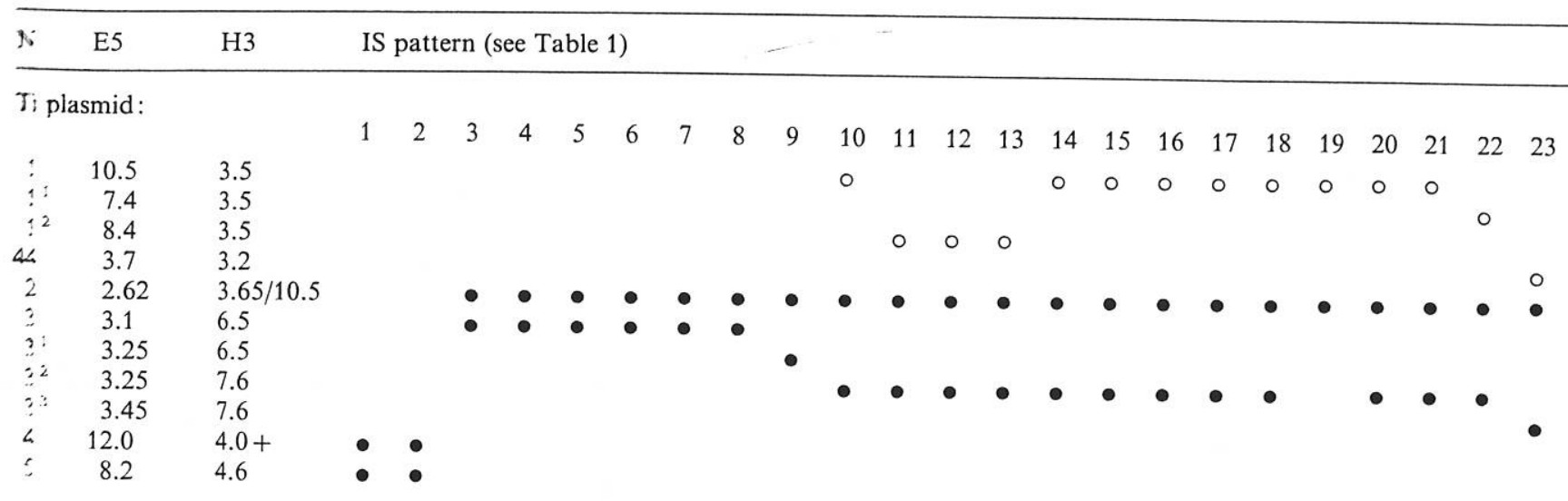

Criromosomal and non-Ti plasmid:

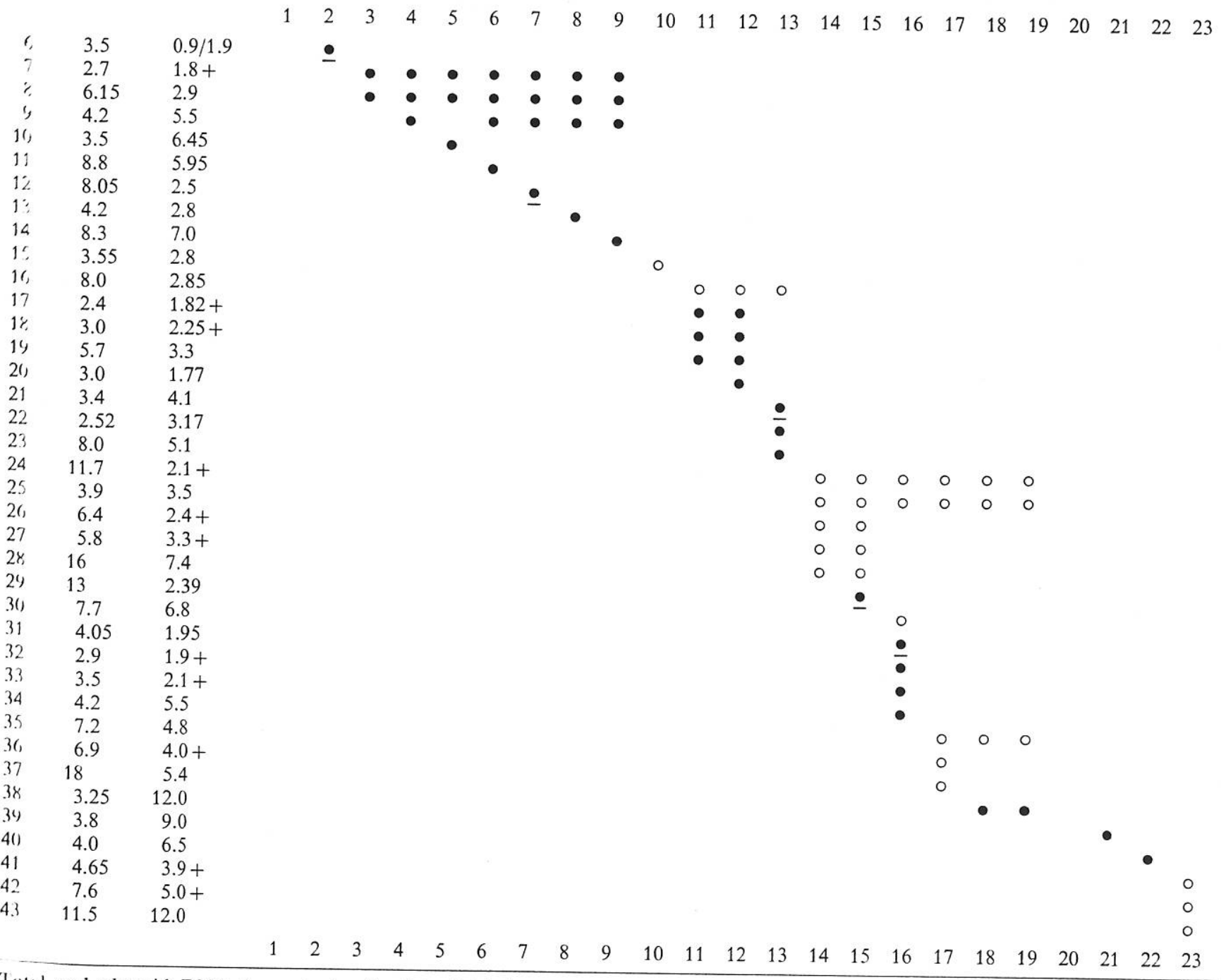

Total and plasmid DNA from strains listed in Table 1 was cut with HindIII or EcoRV and run on agarose gels. Southern blots of these gels were probed with IS866- and IS867-specific probes (see Fig. 1). The sizes of the various fragments indicated are in kb.
l: lements on non-Ti plasmids are underlined N. identification number of IS element (IST-1 to IST-44), characterized by size of restriction fragments; E5, EcoRV; H3, HindIII;
0 , IS $866 ; \bullet$, IS867

as can be seen in Table 2, the two groups of strains with IS pattern 6 (representative strain, 2650; see Table 1 and Fig. 2) and IS pattern 7 (representative strain, 2653) both curry the Ti plasmid-located IST-2 and IST-3 elements, and the chromosomal elements IST-7, IST-8 and IST-9. Strains with pattern 6 carry in addition the chromosomal element IST-11, those with pattern 7 carry IST-12 on a non-Ti plasmid. Strains with pattern 6 and 7 are thus related to each other by common descent from a strain that carries IST-2, IST-3, IST-7, IST-8 and IST-9. Our collection contains six 


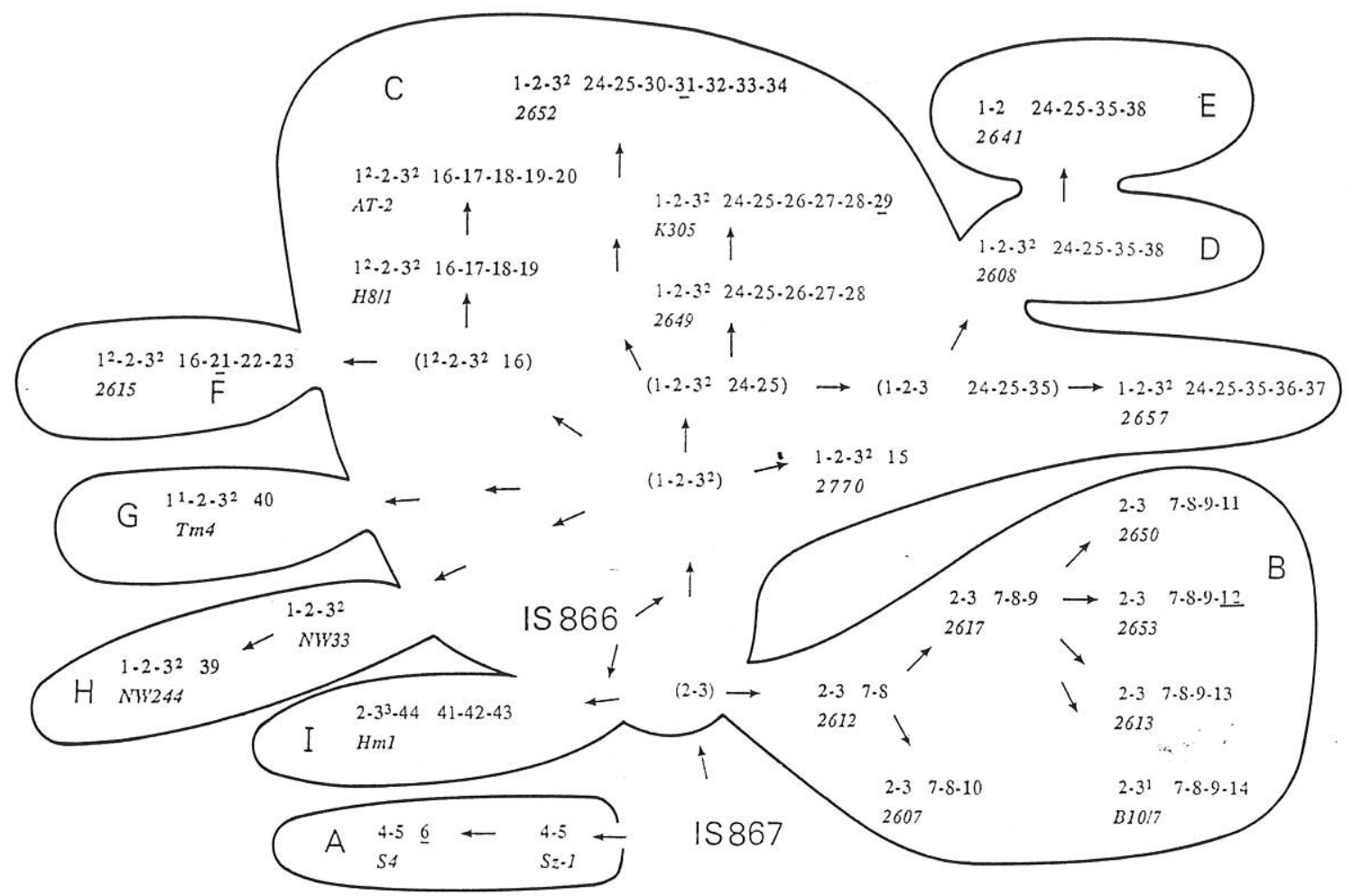

Fig. 2. Phylogenetic tree showing relationships between the isolates described in Table 1. Numbers indicate IST elements identified by the size of the hybridizing EcoRV and HindIII fragments. Numbers in bold face indicate IS867 copies, other numbers indicate IS866 copies: for a description of these numbers, see Table 2. Numbers in italics indicate representative strains. The letters A to I indicate the T-region structure of the particular strain group, as described in Table 3. Underlined numbers indicate copies on non-Ti plasmids

strains with this ancestral pattern, which we have called pattern 4 (representative strain, 2617). By comparing the other patterns described in Table 2, a coherent phylogenetic tree could be constructed (Fig. 2). This tree is composed of the 46 octopine/cucumopine strains, each of which possesses the two characteristic Ti plasmid-located elements IST-2 and IST-3. A separate group contains the 8 vitopine strains, also with two Ti plasmid-located elements: IST-4 and IST-5.

Within the group of 46 IST-2 and IST-3 containing strains, 26 strains contain a second type of IS element, the IS867-related element IS866. One copy of IS866 is located on the Ti plasmid of these strains, in 25 strains within the $\mathrm{TA}$ region (IST-1) and in one strain, $\mathrm{Hm} 1$, outside the TA region (IST-44). IS866 is also found, at various locations, outside the $\mathrm{Ti}$ plasmid. It is striking, that in all strains (except Hm1) the Ti-located copies of IS866 and IS867 are found at the same locations, whereas the chromosomal IS positions vary. We suggest therefore, that the different octopine/cucumopine Ti plasmids were derived from an IST-2/ IST-3 ancestral Ti plasmid, and that the chromosomal IS elements were derived from the Ti plasmid-located elements by replicative transposition. The 14 different types of IS866/ IS867 strains have no chromosomal IS867 copies in common with the IS867 strains. This indicates that the IST-2/ IST-3/IST-1 strains branched off from a primitive IST-2/ IST -3 strain before IST-2 and/or IST-3 started to multiply outside the Ti plasmid.

\section{T-region structure in IS866 and IS867 bearing strains}

Close inspection of IS866 and IS867 patterns allowed us to place the vitopine and octopine/cucumopine strains on a phylogenetic tree. This tree indicated that plasmid and chromosomal IS patterns were correlated. However, the patterns of the Ti plasmid IS copies varied relatively little, and we therefore extended the characterization of the $\mathrm{Ti}$ plasmids by analysis of the structure of the TA and TB region of the Agrobacterium isolates. Fragments of the TL region of Ach5 and of the TB auxin gene region (Fig. 1) were used as probes in Southern hybridization experiments with HindIII digested plasmid DNA of the isolates listed in Table 1. Several patterns could be observed (Table 3):

(a) The vitopine Ti plasmids ( 8 isolates) have very little homology with the T-region probes ("pattern" A).

(b) The octopine/cucumopine strains that only carry IS867 elements ( 20 isolates, exemplified by AB3) show a single HindIII T-region pattern and have a small TA region ("small TA" strains, pattern B; see also Fig. 1).

(c) The octopine/cucumopine strains that carry IS866 and IS867 (26 isolates, exemplified by Tm4) have a large $\mathrm{TA}$ region structure and show different $\mathrm{TA}$ and $\mathrm{TB}$ region structures ("large TA" strains, patterns C, D, E, F, G, $\mathrm{H}$ and $\mathrm{I}$ ). Interestingly, the differences in TA structure are located to the left of the IS866 element. Figure 3 shows the patterns revealed by a probe from the left part of the Ach5 TL region. The large TA region of the Hm1 Ti plasmid is not interrupted by an IS866 element. However, the unexpected size of the HindIII fragment hybridizing to the Ach 5 auxin gene probe $(5.0 \mathrm{~kb}$ instead of $3.7 \mathrm{~kb}$ calculated for a non-interrupted auxin region) suggests that the TA auxin region of $\mathrm{pTiHm} 1$ is interrupted by an unknown sequence of $1.3 \mathrm{~kb}$. Strain 2641 is closely related to 2608 but is deleted in the TB region and lacks the auxin genes and the associated IST-3 element. 
Table 3. T-region structures of octopine/cucumopine and vitopine Ti plasmids

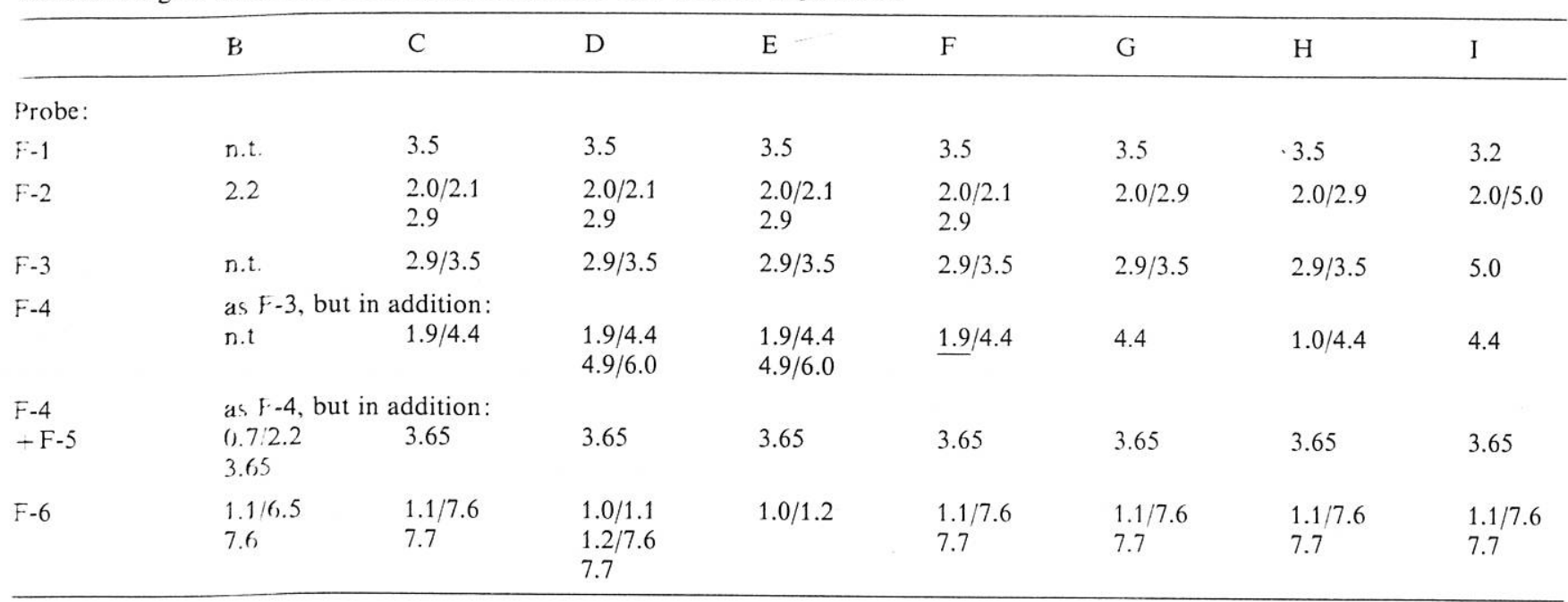

Plasmid DNA of strains listed in Table 1 was isolated, cut with HindIII and separated on agarose gels. Southern blots of these gels were probed with different T-region fragments and with an IS866-specific probe (see Fig. 1). The IS867 fragments hybridizing weakly with the IS866 probe are not indicated. Similarly, the TA region fragments hybridizing with the TB auxin region probe and the TB region fragments hybridizing with the Ach5 auxin probe are not indicated. Weakly hybridizing sequences are underlined; n.t., not tested. The strains belonging to the different T-region types (A-I) are listed in Table 1 and shown in Fig. 3 . Sizes of the fragments indicated are in $\mathrm{kb}$. Pattern A (fragments of 2.8 and $3.2 \mathrm{~kb}$, weakly hybridizing with F-4 and F-5) will be described in detail elsewhere F-1, IS866 probc; F-2, Ach5 $2.7 \mathrm{~kb}$ HindIII (genes 5 and 7); F-3, Ach5 $2.1 \mathrm{~kb}$ HindIII (gene 2): F-4, Ach5 $7.6 \mathrm{~kb}$ BamHI (left-hand part of TL region): F-5, Ach5 $12.6 \mathrm{~kb}$ HindIII (right-hand part of TL region); F-6, TB auxin region of Tm4

\section{Discussion}

Although the basic mechanism of crown gall formation has been elucidated, we still know very little about the phylogenetic relationships and evolutionary origin of the various Agrobacterium isolates and their Ti plasmids, or about the factors that shape their natural distribution. The present study is the first of its kind which attempts to answer these questions. Using the transpositional activity of the IS elements IS866 and IS867 as molecular time markers, we have shown that a large number of biotype III Agrobacterium strains are closcly related and can be placed in a simple evolutionary scheme. Analysis of additional grapevine strains can be expected to lead to the discovery of a number of "missing links" and possibly of new branches. However, we believe that the essential features of the evolution of the IS866 and IS867 strains have now been established. Two primitive strains, each with two Ti plasmid-located IS elements, can be placed at the bottom of two different lines (octopine/cucumopine strains and vitopine strains). Whereas 7 out of 8 vitopine strains contain only the two Ti plasmid elements, the number of IS elements in the octopine/cucumopine strains is found to increase progressively. Remarkably, strains with "small TA" plasmids, all of which lack Ti plasmid-located IS866 elements, also lack chromosomal IS 866 copies. Moreover, none of the "large TA" plasmids is found in a strain with a chromosomal IST background pattern characteristic for strains with "small TA" Ti plasmids. More generally, the different Tregion patterns which we have been able to define for these strains, are strictly correlated with the chromosomal IS patterns.

This indicates that under natural conditions octopine/ cucumopine and vitopine Ti plasmids are not or only rarely transmitted to strains with a different chromosomal background. Likewise. the absence of IS866 or IS867 elements in the 20 biotype III nopaline strains of our collection indi-

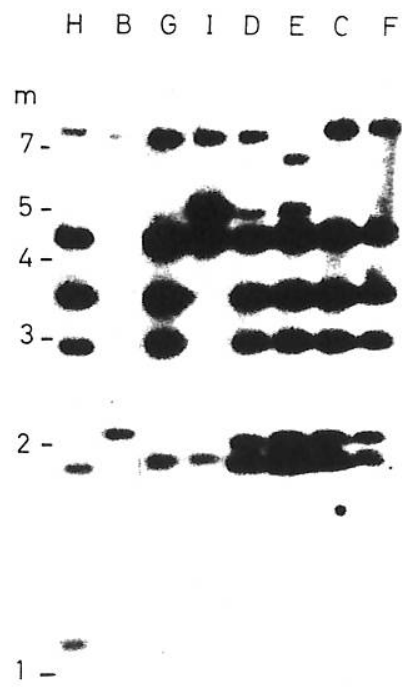

Fig. 3. T-region patterns of representative strains, as revealed by the left-hand fragment of the TL region of pTiAch5. Ti plasmid DNA of AB3 (B), K305 (C), 2608 (D), 2641 (E), 2615 (F), Tm4 $(\mathrm{G})$, NW33 (H) and $\mathrm{Hm} 1$ (I) was digested with HindIII, run on an agarose gel, blotted and hybridized to probe F-4 (Fig. 1). The letters $\mathrm{B}$ to $\mathrm{I}$ indicate the various patterns that could be defined (see also Tables 1 and 3). Pattern A (very weak bands of 2.8 and $3.2 \mathrm{~kb}$; Paulus et al. 1989) is not shown. $\mathrm{m}$ : sizes of DNA marker fragments in $\mathrm{kb}$

cates that the biotype III nopaline Ti plasmids do not move into octopine/cucumopine backgrounds (Paulus et al. 1989). This surprisingly stable association between the $\mathrm{Ti}$ plasmids and their hosts was unsuspected, since Ti plasmids of biotype I strains have been found to be transferable both in vivo and in vitro (Petit et al. 1978). The apparent absence of Ti plasmid transfer could be explained by incompatibility phenomena. Incompatibility has been described for biotype 
I octopine and nopaline strains and was found to be $\mathrm{Ti}$ plasmid encoded (Koekman et al. 1980, 1982). Although incompatibility would prevent Ti plasmid transfer between virulent Agrobacterium strains, Ti plasmid-less biotype III isolates have been found which carry chromosomal IST elements (Otten, unpublished observations) and which could constitute recipients for octopine/cucumopine, nopaline and vitopine Ti plasmids. Possibly, the various biotype III strain types are restricted to specific natural conditions which prevent them from exchanging $\mathrm{Ti}$ plasmids.

The evolutionary tree presented in Fig. 2 indicates that the IS866/IS867 elements played an important role in the evolution of the $\mathrm{Ti}$ plasmids and of the Agrobacterium strains carrying them. According to this tree, the following events marked the evolution of the octopine/cucumopine and vitopine strains:

(1) The IS867 element. found in all octopine/cucumopine strains and the IS867-like sequence found in vitopine strains were originally not present in Agrobacterium biotype III Ti plasmids but were introduced, possibly by conjugation. from other bacteria. One Agrobacterium receptor strain received two IS867 copies on its Ti plasmid and became the ancestor of the octopine/cucumopine family, another strain received two IS867-like copies on its Ti plasmid and became the ancestor of the vitopine family. The introduction of the IS elements could have occurred in two separate steps. However, since no strains were found to carry only one copy, it is possible that the two IS867 copies were introduced together, as part of a large transposon-like structure. In the case of the octopine/cucumopine strains, such a structure would carry the octopine degradation genes (Knauf et al. 1984) and the TB region with its auxin genes (Knauf et al. 1984; Huss et al. 1989). Since the octopine/ cucumopine precursor $\mathrm{Ti}$ plasmid would have contained a TA region with intact auxin genes, not yet interrupted by IS866 (Fig. 1), the arrival of a second set of auxin genes might have allowed a series of mutational changes in the TA auxin region. According to the tree in Fig. 2, the TA region most closely related to the original $\mathrm{TA}$ region is found in strains with pattern $C$.

We know little about the $\mathrm{Ti}$ plasmids of the vitopine strains, and the structure of the vitopine T-regions has yet to be determined. IST -4 and IST- 5 are strongly homologous with IS867, but lack the characteristic internal HindIII sites. This difference suggests that the IS elements of the vitopine strains are not directly derived from those of the octopine/ cucumopine strains but have an independent origin.

(2) One of the octopine/cucumopine bacteria which had acquired the IST-2 and IST- 3 elements lost the TA auxin genes and most of the cytokinin gene, giving rise to the group with $\mathrm{T}$-region pattern $\mathrm{B}$.

(3) In another octopine/cucumopine bacterium carrying IST-2 and IST-3, a new IS element, IS866, was inserted into the $i a a H$ gene of the TA region. The origin of IS866 is unknown, but it probably arrived before the IS867 elements IST-2 and IST-3 started to multiply, as indicated by the fact that the IS867 strains and the IS866/867 strains have no IS867 copies in common outside the ones on the Ti plasmid. One strain, $\mathrm{Hm} 1$, has a large TA region which is different from that of the other large TA strains. The $\mathrm{Hm} 1 \mathrm{TA}$ region is interrupted by a $1.3 \mathrm{~kb}$ DNA fragment without homology to IS866. Instead, pTiHm1 carries an IS866 copy in an unknown area outside the TA region.

(4) After the insertion of IS866 in the TA region of the large TA strains, various changes occurred in the left- hand part of the TA region and in the TB auxin region. These changes led to patterns D, E, F, G, H and I. Pattern $\mathrm{C}$ probably represents the original $\mathrm{T}$-region pattern.

(5) After separation of the octopine/cucumopine strains into two major groups (small TA and large TA strains), the Ti plasmid-located IS elements transposed into various locations on the chromosome or on other plasmids. In the case of the small TA strains, the chromosomal elements IST- 7 and 8 may have been present before the TA deletion occurred, as no small TA strains have yet been found without IST-7 and IST-8. In the case of the large TA strains, 6 different lines can be distinguished, in which both IS866 and IS867 elements accumulate (Fig. 2).

It is unlikely that the insertion of IS866 and IS867 into their characteristic sites on the octopine/cucumopine and vitopine Ti plasmids occurred several times. Consequently, the evolutionary model presented here predicts that the 46 octopine/cucumopine strains of our collection, isolated from different places worldwide (Table 1), are related by common descent from a single bacterial cell, which acquired IST -2 and IST -3 in a spatially and temporally unique transposition event and subsequently underwent divergent evolution. The same holds true for the 8 vitopine strains, which must also have been derived from a single bacterial cell. Octopine/cucumopine strains and vitopine strains together constitute about $40 \%$ of the grapevine strains. The apparently preferential multiplication of two bacterial cells giving rise to a quantitatively important, worldwide population of grapevine-associated strains, indicates a strong selective advantage for these two hypothetical individuals. We suggest that the selective advantage did not reside within the IS elements themselves, but was conferred upon the target plasmids by sequences situated between the two IS copies which together with the IS elements would have formed part of a large transposon. In the case of the octopine/ cucumopine strains such a transposon would comprise a functional set of auxin genes and octopine catabolism genes and would have been inserted into a $\mathrm{Ti}$ plasmid which already contained a $\mathrm{TA}$ region with an octopine synthase gene.

This "transposon hypothesis" is in line with a similar suggestion by Yamada et al. (1986) who proposed a role for the Pseudomonas IS element IS51 in the transfer of auxin genes from Pseudomonas to Agrobacterium. In a preliminary search for IS866 and IS867 in various Pseudomonas savastanoi strains (Otten, unpublished) no homology was found. IS866 and IS867 were also absent from the typical octopine and nopaline biotype I strains like Ach5 or C58 and from biotype II strains (Bonnard et al. 1989b). Further studies are required to determine the origin of the IS866/ IS867 elements. In addition, the transpositional activity of IS866, IS867 and the IST-2/IST-3 region should be tested.

Our studies have shown considerable differences in Tregion structure within the grapevine-associated biotype III strains, part of which can be expected to lead to differences in tumour-inducing properties. Small TA strains like AB3 are virulent on grapevine. Recent results from our laboratory (Paulus, unpublished) indicate that the only essential genes on the AB3 TA region are the $6 b$ gene and the ocs gene, located in the right-hand part of the TA region. The variable left-hand part of the TA region of the large TA strains may result from random deletions within a region that lost its function after the introduction of the TB region. Alternatively, the various structures in this region may represent subtle adaptations to different grapevine varieties or 
to different environmental conditions. To distinguish between these possibilities, it will be important to reconstruct the left-hand side of the original TA region and to test the function of the genes it contains.

Acknowledgements. We thank J. Schell for Ach5 clones, and E. Szegedi and E. Bien for Agrobacterium biotype III strains. F. Paulus was supported by a grant from the French Ministry of Science and Technology in the framework of the "Programme National Vigne". We also thank Moët-Hennessy for additional financial support.

\section{References}

Bien E (1988) Isolierung und Characterisierung von Agrobacterium tumefaciens biovar 3, dem Erreger der Mauke an Reben. Ph.D. Thesis, University of Kaiserslautern, Federal Republic of Germany

Bonnard G, Tinland B, Paulus F, Szegedi E, Otten L (1989a) Nucleotide sequence, evolutionary origin and biological role of a rearranged cytokinin gene isolated from a wide host range biotype III Agrobacterium strain. Mol Gen Genet 216:428-438

Bonnard G, Vincent F, Otten L (1989b) Sequence and distribution of IS866, a novel $\mathrm{T}$ region-associated insertion sequence from Agrobacterium tumefaciens. Plasmid, in press

Buchholz WG, Thomashow MF (1984) Comparison of T-DNA oncogene complements of Agrobacterium tumefaciens tumorinducing plasmids with limited and wide host ranges. J Bacteriol $160: 319-326$

Burr TJ, Katz BH (1983) Isolation of Agrobacterium tumefaciens biovar 3 from grapevine galls and sap and from vineyard soil. Phytopathology 73:163-165

Burr TJ, Katz BH. Bishop AL (1987) Populations of Agrobacterium in vineyard and nonvineyard soils and grape roots in vineyards and nurseries. Plant Dis 71:617-620

Currier TC, Nester EW (1976) Isolation of covalently closed circular DNA of high molecular weight from bacteria. Anal Biochem $76: 431-441$

De Cleene M, Deley J (1976) The host range of crown gall. Bot Rev 42:389-466

Dhaese P, De Greve H, Decraemer H, Schell J, Van Montagu M (1979) Rapid mapping of transposon insertion and deletion mutations in the large Ti-plasmids of Agrobacterium tumefaciens. Nucleic Acids Res 7:1837-1849

Gielen J, Beuckeleer M de, Seurinck J, Deboeck F, De Greve H, Lemmers M, Van Montagu M, Schell J (1984) The complete nucleotide sequence of the TL-DNA of the Agrobacterium tumefaciens plasmid pTiAch5. EMBO J 3:835-846

Guyon P, Chilton M-D, Petit A, Tempé J (1980) Agropine in "null-type". tumors: evidence for the generality of the opine concept. Proc Natl Acad Sci USA 77:2693-2697

Hoekema A, de Pater BS, Fellinger AJ, Hooykaas PJJ, Schilperoort RA (1984) The limited host range of an Agrobacterium tumefaciens strain extended by a cytokinin gene from a wide host range T-region. EMBO J 3:3043-3047

Hood EE, Helmer GL, Fraley RT, Chilton M-D (1986) The hypervirulence of Agrobacterium tumefaciens A281 is encoded in a region of pTiBo542 outside of T-DNA. J Bacteriol 168:1291-1301

Huss B, Bonnard G, Otten L (1989) Isolation and functional analysis of a set of auxin genes with low root-inducing activity from an Agrobacterium tumefaciens biotype III strain. Plant Mol Biol $12: 271-283$

Jäger J (1988) Untersuchungen zur Epidemiologie und Bekämp-

\section{Note added in proof}

Recently we have found that some of the variability in the hybridization patterns obtained with probe F-2 and F-4 (the left hand part of the TL DNA of Ach5) is due to the presence of chromosomal sequences hybridizing to these probes. Therefore, patterns $\mathrm{F}$ and $\mathrm{D}$ can be grouped with pattern $\mathrm{C}$. fung von Agrobacterium tumefaciens (Smith and Townsend, Conn.) dem Erreger der Mauke (Crown gall) an Reben. Ph.D. Thesis, University of Kaiserslautern, Federal Republic of Germany

Kerr A, Panagopoulos CG (1977) Biotype of Agrobacterium radiobacter var. tumefaciens and their biological control. Phytopath Z 90:172-179

Knauf VC, Panagopoulos CG, Nester EW (1982) Genetic factors controlling the host range of Agrobacterium tumefaciens. Phytopathology $72: 1545-1549$

Knauf VC, Yanofsky M, Montoya A. Nester EW (1984) Physical and functional map of an Agrobacterium tumefaciens plasmid that confers a narrow host range. J Bacteriol 160:564-568

Koekman BP, Hooykaas PJJ, Schilperoort RA (1980) Localization of the replication control region of the octopine $\mathrm{Ti}$ plasmid. Plasmid 4:184-195

Koekman BP, Hooykaas PJJ, Schilperoort RA (1982) A functional map of the replicator region of the octopine Ti plasmid. Plasmid 7:119-132

Leemans J, Hernalsteens J-P, Deblaere R, De Greve H, ThiaToong L, Van Montagu M, Schell J (1983) Genetic analysis of T-DNA and regeneration of transformed plants. In: Pühler A (ed) Molecular genetics of the bacteria plant interaction. Springer, Berlin, pp 322-330

Loubser JT (1978) Identification of Agrobacterium tumefaciens biotype 3 on grapevine in South Africa. Plant Dis Rep 62:730-731

Nester EW, Gordon MP, Aamasino RM, Yanofsky M (1984) Crown gall: a molecular and physiological analysis. Annu Rev Plant Physiol 35:387-413

Otten L, Piotrowiak G, Hooykaas P, Dubois M, Szegedi E, Schell J (1985) Identification of an Agrobacterium tumefaciens pTiB6S3 vir region fragment that enhances the virulence of pTiC58. Mol Gen Genet 199:189-193

Paulus F, Huss B, Bonnard G, Ride M, Szegedi E, Tempé J, Petit A, Otten L (1989) Molecular systematics of biotype III Ti plasmids of Agrobacterium tumefaciens. Mol Plant Microbe Interact 2:64-74

Perry KL, Kado CI (1982) Characteristics of Ti plasmids from broad-host range and ecologically specific biotype 2 and 3 strains of Agrobacterium tumefaciens. J Bacteriol 151:343-350

Petit A, Tempé J, Kerr A, Holsters M, Van Montagu M, Schell J (1978) Substrate induction of conjugative activity of Agrobacterium tumefaciens $\mathrm{Ti}$ plasmids. Nature 271:570-571

Smith EF, Townsend CO (1907) A plant tumour of bacterial origin. Science 25:671-673

Süle S (1978) Biotypes of Agrobacterium tumefaciens in Hungary. J Appl Bacteriol 44:207-213

Szegedi E, Csako M, Otten L, Koncz CS (1988) Opines in crown gall tumours induced by biotype 3 isolates of Agrobacterium tumefaciens. Physiol Mol Plant Pathol 32:237-247

Thomashow MF, Panagopoulos CG, Gordon MP, Nester EW (1980) Host range of Agrobacterium tumefaciens is determined by the Ti plasmid. Nature 283:794-796

Yamada T, Lee PD, Kosuge T (1986) Insertion sequence elements of Pseudomonas savastanoi: nucleotide sequence and homology with Agrobacterium tumefaciens transferred DNA. Proc Natl Acad Sci USA 83:8263-8267

Zambryski P, Tempé J, Schell J (1989) Transfer and function of T-DNA genes from Agrobacterium $\mathrm{Ti}$ and $\mathrm{Ri}$ plasmids in plants. Cell 56:193-201

Communicated by H. Saedler

Received May 17, 1989 